\title{
LOKAKARYA MANAJEMEN BERBASIS SEKOLAH (MBS) DAN IMPLEMENTASI PADA KURIKULUM 2013 DI SEKOLAH DASAR (SD) DI SUKABUMI, INDONESIA
}

\author{
${ }^{1}$ Novi Andri Nurcahyono, ${ }^{2}$ Astri Sutisnawati dan ${ }^{2}$ Iis Nuraisah \\ ${ }^{1}$ Program Studi Pendidikan Matematika, ${ }^{2}$ Program Studi Pendidikan Guru Sekolah Dasar, FKIP, \\ Universitas Muhammadiyah Sukabumi, Indonesia \\ E-mail: nanurcahyono@gmail.com
}

\begin{abstract}
The purpose of this Workshop is to help teachers with regard to improving teaching and learning activities and school management and their implementation in the 2013 curriculum in Elementary Schools. Participants in this activity were elementary school teacher representatives in Limbangan Village, Sukaraja District, Sukabumi Regency and all KKN students in Limbangan Village, Sukaraja District, Sukabumi District. The workshop was conducted in 3 stages, namely the prefix stage, the core stage, and the final stage. The results obtained after the workshop were the commitment of teachers to implement MBS in the learning process with the 2013 curriculum in their respective schools. The difficulties experienced by teachers related to the development of learning evaluation in the 2013 curriculum. In this workshop, it was also found the fact that most teachers indirectly applied MBS in their respective schools.
\end{abstract}

Keywords: 2013 Curriculum, School Based Management, Elementary School

\begin{abstract}
Abstrak
Tujuan dari Lokakarya ini adalah membantu guru berkenaan dengan peningkatan kegiatan belajar mengajar dan manajemen sekolah serta implementasinya pada kurikulum 2013 di Sekolah Dasar. Peserta dalam kegiatan ini yaitu perwakilan guru SD/sederajat yang terdapat di Desa Limbangan Kecamatan Sukaraja, Kabupaten Sukabumi dan seluruh mahasiswa KKN di Desa Limbangan Kecamatan Sukaraja Kabupaten Sukabumi. Metode Lokakarya dilakukan dalam 3 tahap, yaitu tahap awalan, tahap inti, dan tahap akhir. Hasil yang didapat setelah pelaksanaan lokakarya adalah komitmen guru untuk mengimplementasikan MBS pada proses pembelajaran dengan kurikulum 2013 di sekolah masingmasing. Kesulitan yang dialami guru terkait pengembangan evaluasi pembelajaran di kurikulum 2013. Pada lokakarya ini juga ditemukannya fakta bahwa sebagian besar guru secara tidak langsung telah menerapkan MBS di Sekolah mereka masing-masing.
\end{abstract}

Kata Kunci: Kurikulum 2013, Manajemen Berbasis Sekolah, Sekolah Dasar.

\section{PENDAHULUAN}

Perubahan paradigma tentang penyelenggaraan pendidikan di Indonesia dari sentralistik menjadi desentralistik didasari berlakunya otonomi daerah ${ }^{1}$. Otonomi daerah memungkinkan pemerintah pusat memberikan kewenangan termasuk salah satunya di bidang pendidikan kepada masing-masing daerah untuk mengelola dan mengembangkan daerahnya sesuai dengan potensi yang dimilikinya. Model otonomi di bidang pendidikan yang diterapkan di sekolah adalah Manajemen Berbasis Sekolah (MBS).

MBS merupakan model manajemen yang memberikan otonomi lebih besar kepada sekolah dan mendorong pengambilan keputusan partisipatif yang melibatkan secara langsung semua warga sekolah (guru, siswa, kepala sekolah, karyawan, orang tua siswa dan masyarakat) untuk meningkatkan mutu sekolah berdasarkan kebijakan

\footnotetext{
${ }^{1}$ Undang-Undang Republik Indonesia Nomor 2 Tahun 2014 tentang Pemerintahan Daerah
} 
pendidikan nasional. ${ }^{2}$ Sesuai dengan definisi tersebut, MBS diharapkan dapat meningkatkan peran serta masyarakat terutama orang tua peserta didik dalam penyelenggaraan pendidikan yang selama ini masih kurang. Sebelum hadirnya MBS, paradigma partisipasi masyarakat dalam pendidikan hanya dalam input pendidikan berupa sumbangan uang. Saat ini, paradigma masyarakat dalam konteks MBS berupa partisipasi dalam input, proses, dan kontrol kualitas output pendidikan diwadahi dalam formula komite sekolah/dewan sekolah. Fungsi dan peran utama Komite Sekolah adalah sebagai mitra kerja, penasihat, penghubung dengan masyarakat, dan pengendali mutu. Peningkatan kualitas adalah tanggung jawa semua pihak, sehingga semua harus berperan ${ }^{3}$.

Selain kurangnya peran masyarakat, masalah lainnya dalam penyelenggaraan pendidikan adalah kebijakan yang ada terlalu berorientasi pada keluaran pendidikan atau masukan sehingga Proses Belajar Mengajar (PBM) tidak diperhatikan. Namun, dengan MBS, sekolah mempunyai kewenangan penuh dalam merencanakan, mengorganisasikan, mengawasi, mempertanggungjawabkan serta memimpin sumber daya yang ada untuk mengoptimalkan pelaksanaan pembelajaran sesuai tujuan yang telah ditetapkan. MBS harus memfasilitasi pengembangan Standar Nasional Pendidikan yang meliputi Standar Isi, Standar Kompetensi Lulusan, Standar Proses, Standar Pendidik dan Tenaga Kependidikan, Standar Sarana dan Prasarana, Standar Pengelolaan, Standar Pembiayaan, dan Standar Penilaian pendidikan sehingga proses pembelajaran jelas diperhatikan.

Hal ini sesuai dengan tujuan MBS yaitu meningkatkan mutu pendidikan, mengefektif dan efisienkan pengelolaan dan pemberdayaan sumber daya yang tersedia, dan meningkatkan pelayanan pendidikan kepada siswa. Berdasarkan kebijakan pendidikan nasional serta peraturan perundang-undangan yang berlaku, dengan otonomi tersebut sekolah diberikan kewenangan dan tanggungjawab untuk mengambil keputusan-keputusan sesuai dengan kebutuhan, kemampuan, dan tuntutan sekolah serta masyarakat atau stakeholder yang ada. MBS mampu memahami keahlian dan kemampuan orang-orang yang bekerja di sekolah, sehingga dapat meningkatkan kualitas pembelajaran dan kemampuan personil sekolah dihargai sehingga menimbulkan rasa percaya diri. MBS memunculkan komitmen dan tanggung jawab dalam setiap pengambilan keputusan di sekolah. Keputusan yang diambil sekolah memiliki akuntabilitas, sehingga mereka dapat menerima konsekuensi atas keputusan yang diambil dan memiliki komitmen untuk mencapai tujuan yang ditetapkan bersama. Keputusan yang diambil pada tingkat sekolah akan lebih rasional karena mereka tau kekuatannya sendiri, terutama kekuatan keuangannya. Pengambilan keputusankeputusan tersebut akan memunculkan pemimpin di sekolah. MBS dapat meningkatkan

\footnotetext{
2 Sukmawati. 2011. Strategi Meningkatkan Mutu Pendidikan Melalui Manajemen Berbasis Sekolah. Cakrawala Kependidikan. Volume 9 (2): 105-211.

${ }^{3}$ Roni Nursyamsu. 2018. Pelatihan Peningkatan Kapasitas Pemuda Dan Pembuatan Program Kerja Pada Organisasi Pemuda Desa Cibinuang, Kabupaten Kuningan, Empowerment : Jurnal Pengabdian Masyarakat, E-Issn 2598-2052 Vol. 01 Nomor 01. 2018. 37- 44
} 
kualitas, kuantitas, dan fleksibilitas komunikasi setiap komunitas sekolah dalam rangka pencapaian kebutuhan sekolah.

Menurut BPPN yang bekerjasama dengan Badan Dunia ada faktor-faktor MBS yang perlu diperhatikan, yaitu kewajiban sekolah, Kebijakan dan Prioritas Pemerintah, Peranan Orangtua dan Masyarakat, Peranan Profesionalisme dan Manajerial, serta Pengembangan Profesi. Perlu juga diperhatikan syarat penerapan MBS, yaitu MBS harus mendapatkan dukungan staf sekolah, pelaksanaannya hendaknya bertahan dan minimal 5 tahun penerapan, pelatihan dan peningkatan komunikasi antara tingkat dinas dan sekolah, dukungan anggaran pelatihan dan waktu, adanya kebijakan dan dukungan dari tingkat pusat dan daerah terhadap sekolah. Dengan demikian terdapat strategi pelaksanaan di tingkat sekolah yang meliputi Penyusunan basis data dan profil sekolah yang lebih presentatif, akurat, valid dan secara sistematis menyangkut berbagai aspek akademis, administratif (guru, murid, staf) dan keuangan, Melakukan evaluasi sekolah untuk menganalisis kekuatan dan kelemahan mengenai sumber daya sekolah, personil sekolah dan kinerja dalam pengembangan kurikulum dan murid, Mengidentifikasi kebutuhan sekolah dan merumuskan visi, misi dan tujuan dalam penyelenggaraan pendidikan bermutu, Merencanakan program tindakan jangka pendek, menengah dan panjang, Pengembangan strategi jangka pendek dan skala prioritas, serta Melakukan monitoring dan evaluasi.

Sekolah yang menerapkan MBS mempunyai sejumlah ciri yaitu memiliki tingkat kemandirian yang tinggi, bersifat adaptif, antisipatif, dan proaktif, bertanggungjawab terhadap kinerja sekolah, memiliki jiwa wirausaha yang tinggi, mempunyai komitmen yang tinggi, menjadikan prestasi sebagai acuan dalam penilaian, memiliki kemampuan memberdayakan masyarakat untuk berpartisipasi aktif, serta meningkatnya kualitas proses pembelajaran. Hal ini sesuai karakteristik keberhasilan implementasi MBS yaitu peningkatan kualitas partisipasi masyarakat dan orangtua, peningkatan transparansi dan akuntabilitas pengelolaan sekolah, peningkatan kemandirian sekolah dalam mewujudkan visi dan misi, peningkatan kualitas layanan sekolah, serta peningkatan kesejahteraan materil dan non materil. Dengan demikian, jelaslah bahwa MBS perlu dilakukan. Hal ini ditegaskan bahwa pengelolaan satuan pendidikan dilaksanakan berdasarkan standar pelayanan minimal dengan prinsip manajemen berbasis sekolah. ${ }^{4}$

Pendidikan dasar merupakan pendidikan sembilan tahun, terdiri atas program 6 tahun di SD, dan program 3 tahun di SLTP, dengan demikian SD adalah salah satu bentuk pendidikan pada jenjang pendidikan dasar ${ }^{5}$. Buku I Kurikulum Pendidikan Dasar menjelaskan bahwa pendidikan dasar bertujuan memberikan bekal kemampuan dasar kepada siswa untuk mengembangkan kehidupannya sebagai pribadi, anggota masyarakat, warga negara dan anggota umat manusia serta mempersiapkan siswa untuk mengikuti pendidikan menengah. Rintisan MBS di SD/MI menekankan pada tiga komponen yaitu MBS, peran serta masyarakat (PSM), dan PAKEM.

\footnotetext{
${ }^{4}$ Undang-Undang Republik Indonesia Nomor 20 Tahun 2003 Tentang Sistem Pendidikan Nasional.

${ }^{5}$ Peraturan Pemerintah Republik Indonesia Nomor 28 Tahun 1990 Tentang Pendidikan Dasar.
} 
Temuan di lapangan menunjukan Perencanaan, pelaksanaan, serta monitoring dan evaluasi program di sejumlah sekolah sudah melibatkan pihak yang berkepentingan (stakeholder) meskipun peran kepala sekolah masih dominan, Sebagian sekolah masih lebih memfokuskan perhatiannya pada pembangunan fisik, Perencanaan dan pengalokasian anggaran di beberapa sekolah untuk peningkatan mutu pembelajaran belum menjadi prioritas, Sebagian sekolah sudah membuat RAPBS dengan mengintegrasikan komponen dana dari berbagai sumber, seperti: APBD, orangtua, masyarakat, dan sumber-sumber lainnya namun sebagian yang lain belum, Beberapa sekolah masih mengalami kesulitan dalam menyusun RPS, maupun RAPBS, serta ringkasannya. Berdasarkan temuan tersebut, serta pentingnya tujuan serta manfaat MBS maka perlu dilakukan lokakarya MBS di sekolah terutama SD karena sebagai lembaga yang memberikan bekal kemampuan dasar kepada siswa untuk mengembangkan kehidupannya sebagai pribadi, anggota masyarakat, warga negara dan anggota umat manusia.

\section{METODE PELAKSANAAN}

Kegiatan ini dilaksanakan pada hari Senin, tanggal 27 Agustus 2018, di SD N 1 Cidadap Kecamatan Sukaraja Kabupaten Sukabumi. Kegiatan ini diawali dengan mengidentifikasi permasalahan yang dihadapi mitra untuk kemudian ditawarkan solusi untuk memecahkan permasalahan tersebut. Salah satu permasalahan pokok yang dihadapi mitra yaitu kurangnya motivasi guru SD dalam mengembangkan kompetensi yang dimilikinya. Kompetensi guru yang dapat dikembangkan dalam hal ini terkait manajemen berbasis sekolah (MBS). Dengan permasalahan tersebut maka solusi yang ditawarkan yaitu diadakannya Lokakarya tentang pentingnya MBS di SD. Lokakarya ini diadakan guna meningkatkan mutu sekolah dan cara mengimplementasikan MBS dalam kurikulum 2013. Peserta dalam kegiatan ini yaitu perwakilan guru SD/sederajat yang terdapat di Desa Limbangan Kecamatan Sukaraja, Kabupaten Sukabumi, yakni guru SD Negeri 1 Cidadap, SD Negeri 3 Cidadap, SD Negeri Gintung, SD Negeri 2 Sukaraja, SD Negeri Cisarua dan MI Nagrak dan seluruh mahasiswa KKN Tematik MBS di Desa Limbangan Kecamatan Sukaraja Kabupaten Sukabumi.

\section{HASIL DAN PEMBAHASAN}

Hasil kegiatan pengabdian masyarakat ini terbagi menjadi beberapa tahap, yakni antara lain :

\section{Tahap Awalan}

Pada tahap ini diawali dengan pemaparan umum terkait pentingnya manajemen berbasis sekolah dan peran guru dalam meningkatkan mutu sekolah. Guru diberikan motivasi agar dapat mengoptimalkan kompetensi yang dimiliki, khususnya kompetensi professional. Kompetensi ini berkaitan dengan kualitas dan kemampuan guru dalam pelaksanaan proses pembelajaran sehingga, sangat berpengaruh terhadap peningkatan mutu pendidikan. 


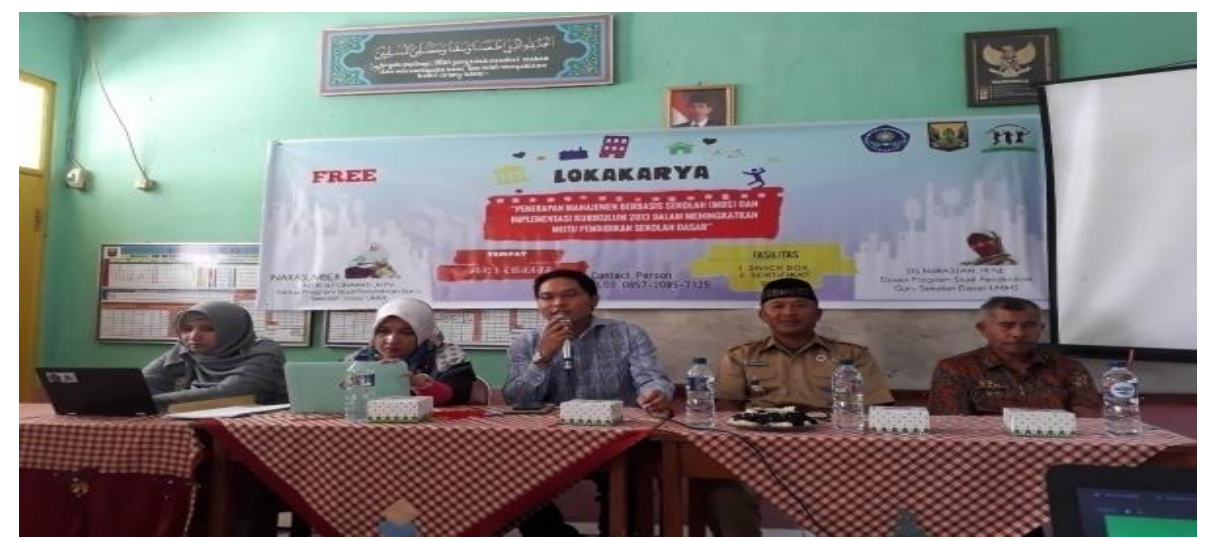

Gambar 1. DPL Memberikan Pengantar dalam Lokakarya Implementasi MBS di SD

2. Tahap Inti

Tahap inti terbagi menjadi dua sesi kegiatan. Sesi pertama yaitu pemaparan materi tentang manajemen berbasis sekolah di SD. Kegiatan ini dimulai dengan memaparkan pola manajemen pendidikan masa depan, mendefinisikan MBS menurut beberapa ahli, alasan menggunakan MBS, sejarah perkembangan MBS di Indonesia, paradigma konsep MBS, prinsip MBS, ciri sekolah yang menerapkan MBS, tujuan dan manfaat MBS, faktor-faktor yang perlu diperhatikan dalam MBS, cirri-ciri MBS, paradigm baru partisipasi masyarakat dalam pendidikan, syarat penerapan MBS, kerangka kerja MBS, hingga kaitannya aplikasi MBS di SD serta indikator keberhasilannya. Selain itu disampaikan pula strategi pelaksanaan di tingkat sekolah. Sedangkan sesi kedua yaitu pemaparan materi tentang kurikulum 2013 dan bagaimana menerapkan MBS dalam kurikulum 2013. Pada sesi kedua ini materi tentang kurikulum 2013 yang disampaikan lebih banyak terkait dengan perangkat pembelajan dan penerapannya di dalam proses pembelajaran.

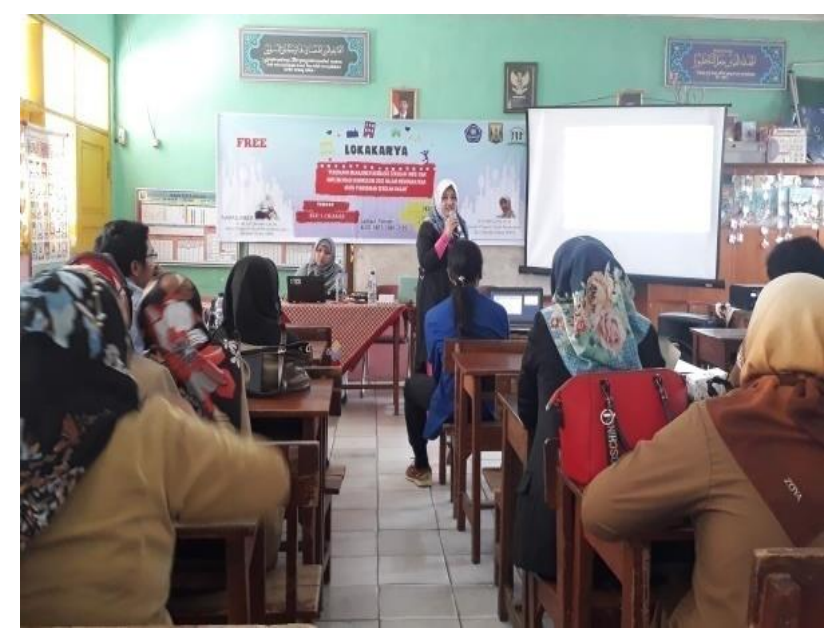

Gambar 2. Pemaparan Materi oleh Narasumber 1 (satu) untuk Sesi 1(satu)

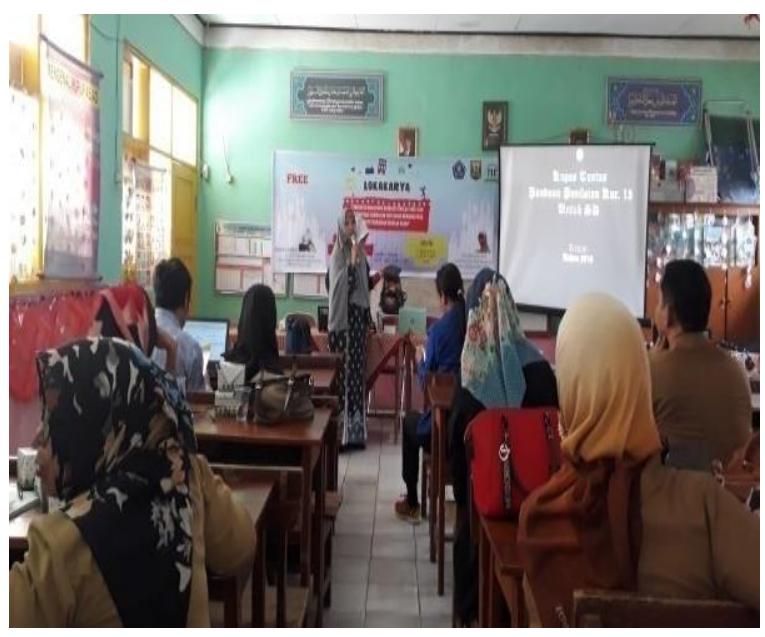

Gambar 3. Pemaparan Materi oleh Narasumber 2(dua) untuk Sesi 2(dua). 


\section{Tahap Akhir}

Pada tahap ini dilakukan tanya jawab oleh peserta kepada nara sumber. Beberapa pertanyaan yang diutarakan yaitu terkait dengan beberapa kendala yang dihadapi guru dalam mengimplementasikan MBS dan terkait pengembangan evaluasi pembelajaran di kurikulum 2013. Evaluasi ini disesuaikan dengan kondisi di masing-masing sekolah terkait karakteristik siswa dan kemampuan sekolah dalam hal ini sumber daya manusia dan pendanaan.

Selanjutnya kegiatan yang dilakukan adalah penutupan yang diakhiri dengan foto bersama sebagai dokumentasi.

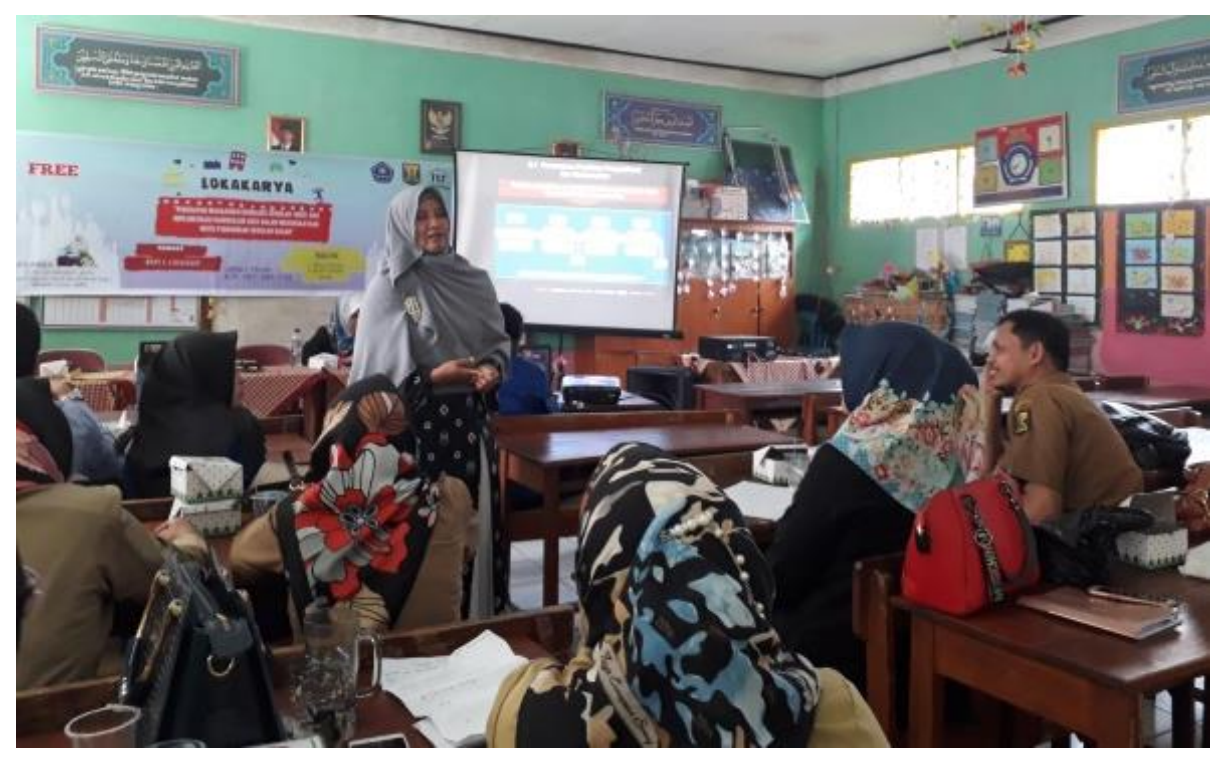

Gambar 4. Pemaparan Jawaban Narasumber Atas Pertanyaan Peserta

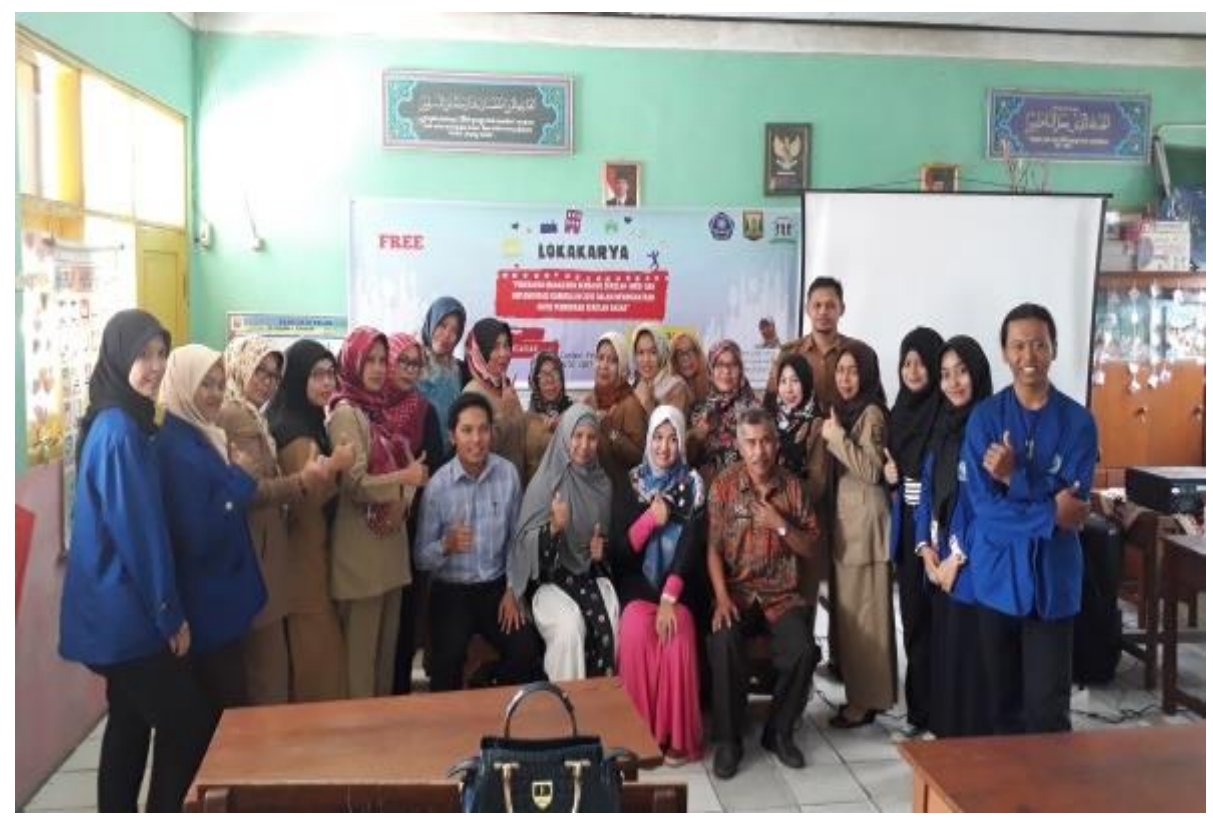


Gambar 5 .Foto Bersama Antara DPL, Narasumber dan Peserta Lokakarya

\section{SIMPULAN}

Simpulan dari kegiatan ini yaitu sebagian besar guru secara tidak langsung telah menerapkan MBS di Sekolah mereka masing-masing. Hal ini ditunjukkan dari beberapa aktivitas guru yang diutarakan ketika sesi tanya jawab dan beberapa ornament yang terdapat di dalam kelas seperti portofolio siswa, beberapa kreasi siswa dan sebagainya. Akan tetapi guru kurang paham bahwa yang dilakukannya tersebut sudah merupakan bagian dari implementasi manajemen berbasis sekolah pada kurikulum 2013.

\section{SARAN}

Adapun saran yang diberikan yaitu hendaknya guru lebih aktif dalam mencari informasi terkait manajemen berbasis sekolah dari berbagai sumber, sehingga guru dapat lebih menggali potensi yang dimilikinya dalam memudahkan guru mengembangkan kompetensinya. Selain itu guru juga hendaknya dapat memanfaatkan fasilitas yang ditawarkan oleh narasumber yaitu berupa bimbingan terkait publikasi karya ilmiah baik dalam prosiding maupun jurnal.

\section{UCAPAN TERIMA KASIH}

Ucapan terima kasih disampaikan kepada seluruh pihak yang telah membantu sehingga kegiatan ini berjalan dengan lancar sesuai dengan harapan, beberapa diantaranya yakni: 1) LPPM UMMI yang telah memberikan dana stimulan guna terselenggaranya kegiatan ini; 2) Koordinator KKN Tematik MBS Kecamatan Sukaraja yang telah memberikan arahan dan masukan; 3) Kepala Desa Limbangan sebagai narahubung antara mahasiswa dengan seluruh SD yang terdapat di desa Limbangan; 4) Kepala Sekolah SD Negeri 1 Cidadap yang telah memberikan izin lokasi pelaksanaan kegiatan ini; dan 5) Seluruh mahasiswa KKN tematik MBS UMMI 2018 di desa Limbangan, Sukaraja, Sukabumi.

\section{DAFTAR PUSTAKA}

Sukmawati. 2011. Strategi Meningkatkan Mutu Pendidikan Melalui Manajemen Berbasis Sekolah. Cakrawala Kependidikan. Vol. 9 (2): 105-211.

Roni Nursyamsu. 2018. Pelatihan Peningkatan Kapasitas Pemuda Dan Pembuatan Program Kerja Pada Organisasi Pemuda Desa Cibinuang, Kabupaten Kuningan, Empowerment : Jurnal Pengabdian Masyarakat, E-Issn 2598-2052

Vol. 01 Nomor 01. 2018. 37- 44.

Undang-Undang Republik Indonesia Nomor 20 Tahun 2003 Tentang Sistem Pendidikan Nasional.

Undang-Undang Republik Indonesia Nomor 23 Tahun 2104 tentang Pemerintahan Daerah.

Peraturan Pemerintah Republik Indonesia Nomor 28 Tahun 1990 Tentang Pendidikan 